\title{
Características de fermentação da silagem de cana-de-açúcar tratada com uréia, zeólita, inoculante bacteriano e inoculante bacteriano/enzimático
}

[Fermentation of sugarcane silage treated with urea, zeolita, bacteria inoculant and bacteria/enzymatic inoculant]

\author{
D.A. Ferreira ${ }^{1}$, L.C. Gonçalves ${ }^{2}$, L.R. Molina ${ }^{2}$, A.G. Castro Neto ${ }^{3}$, T.R. Tomich ${ }^{4}$ \\ ${ }^{1}$ Aluno de pós-graduação - EV-UFMG - Belo Horizonte, MG \\ ${ }^{2}$ Escola de Veterinária - UFMG \\ Caixa Postal 567 \\ 30123-970 - Belo Horizonte, MG \\ ${ }^{3}$ Médico veterinário autônomo \\ ${ }^{4}$ Embrapa Pantanal - Corumbá, MS
}

\begin{abstract}
RESUMO
Estudaram-se as características de fermentação da cana-de-açúcar (RB72454) submetida aos tratamentos: controle; $0,5 \%$ uréia; $0,5 \%$ zeólita; $0,5 \%$ uréia e $0,5 \%$ zeólita; inoculante bacteriano comercial; inoculante bacteriano/enzimático comercial. O material ensilado foi aberto com um, três, cinco, sete, 14,28 e 56 dias de fermentação e analisado quanto aos teores de $\mathrm{MS}$, carboidratos solúveis, $\mathrm{PB}, \mathrm{NNH}_{3} / \mathrm{NT}, \mathrm{pH}, \mathrm{FDN}$, FDA, celulose, hemicelulose, lignina e DIVMS. Observou-se redução do conteúdo de MS em todas as silagens, com média de $21,1 \%$, em relação ao material original $(28,7 \%)$. A concentração média de carboidratos solúveis no material original foi de $19,7 \%$ e, após 56 dias de fermentação, foi de $0,92 \%$. A concentração de PB das silagens testemunha e tratadas com zeólita, inoculante comercial bacteriano e inoculante comercial bacteriano/enzimático variou entre $2,1 \%$ e $3,1 \%$ e naquelas que receberam uréia e uréia+zeólita foi de $8,4 \%$. Os teores de NNH3/NT foram inferiores a $10 \%$ nas silagens testemunha e tratadas com zeólita, inoculante bacteriano comercial e inoculante bacteriano/enzimático comercial, entretanto foi de $30,4 \%$ e $31,1 \%$ nas silagens com uréia e uréia+zeólita, respectivamente. No primeiro dia de fermentação, o pH apresentou média de 3,75. Após 56 dias de fermentação, as concentrações de FDN, FDA, celulose e hemicelulose aumentaram, apresentando média entre os tratamentos de $68,6 \%, 39,6 \%$, $34,5 \%$ e $29,1 \%$, respectivamente. O coeficiente de DIVMS reduziu-se com a ensilagem, em todos os tratamentos avaliados, sendo de $57,6 \%$ no material original e média de $47,6 \%$ nas silagens.
\end{abstract}

Palavras-chave: cana-de-açúcar, silagem, aditivos

\begin{abstract}
The characteristics of fermentation of sugarcane (RB72454) submitted to the treatments control; $0.5 \%$ urea; $0.5 \%$ zeolita; $0.5 \%$ urea and $0.5 \%$ zeolita; commercial bacterial inoculant and commercial bacterial/enzymatic inoculant were studied. The material stored in silos was opened on 1, 3, 5, 7, 14, 28 and 56 days of fermentation and was analysed for grades of $M S$, soluble carbohydrates, $P B, \mathrm{NNH}_{3} / \mathrm{NT}$, pH, FDN, FDA, cellulosis, hemicellulosis, lignin and DIVMS. The reduction of the MS content of the silos was observed, with average of $21.1 \%$ compared to the original material $(28.7 \%)$. The concentration of carbohydrates soluble on the original material was $19.7 \%$ and, after 56 days of fermentation, it was $0.92 \%$. The concentration of $P B$ in the control silage and treated with zeolita, commercial bacterial inoculant and commercial bacterial/enzymatic inoculant varied between $2.1 \%$ and $3.1 \%$ and in thoses that received urea and urea+zeolita was $8.4 \%$. The grades of $\mathrm{NNH}_{3} / \mathrm{NT}$ were lower than $10 \%$ in the control silage and treated with zeolita, commercial bacterial inoculant and commercial bacterial/enzymatic inoculant. However, they were $30.4 \%$ and $31.1 \%$ in the silage with urea and urea+zeolita, respectively. On the first day of fermentation, the $\mathrm{pH}$ presented average of 3.75. After 56
\end{abstract}

Recebido em 7 de julho de 2005

Aceito em 3 de janeiro de 2007

E-mail: luciocg@vet.ufmg.br 
days of fermentation, the concentration of FDN, FDA, cellulosis and hemicellulosis increased, presenting averages considering the treatments of $68.6 \%, 39.6 \%, 34.5 \%$ and $29.1 \%$, respectively. The coefficient of DIVMS reduced with the fermentation, in all the evaluated treatments, being of $57.6 \%$ in the original material and averaging $47.6 \%$ in the silages.

Key words: sugar cane, silage, additives

\section{INTRODUÇÃO}

A baixa produção de forragem, durante o período seco, tem sido apontada como um dos fatores que mais contribui para a baixa produtividade dos rebanhos, sendo responsável pela queda acentuada da produção leiteira, pela perda de peso dos animais de corte e pela grande variação da capacidade de suporte dos pastos que, geralmente, é estabelecida tomando-se por base um período de 12 meses, dificultando a economia da atividade pecuária.

A cana-de-açúcar (Saccharum officinarum L.) é um recurso forrageiro tradicionalmente utilizado para ruminantes (Burgi, 1995), principalmente no período seco, no qual esta cultura atinge sua maturidade e apresenta maior valor nutritivo em decorrência do acúmulo de açúcares em seus tecidos, compensando a redução do valor nutritivo (Banda e Valdez, 1976). Dentre as principais características da cana-de-açúcar destacam-se: grande produção de forragem por área, com média de 69,5t/ha, no Brasil (Bulletin..., 2002); menor custo por unidade de matéria seca produzida em relação à culturas tradicionalmente utilizadas na alimentação de ruminantes, como o milho (Zea mays); período de colheita, ou maior disponibilidade, coincidente com o período de escassez de forragem nas pastagens; disponibilidade relativamente constante durante o período de colheita, que varia de maio a novembro, dependendo dos cultivares utilizados; relativa simplicidade no estabelecimento e manejo da cultura; e manutenção do valor nutritivo por longo espaço de tempo após a maturidade (Peixoto, 1986; Silva, 1993).

O maior problema da utilização da cana-deaçúcar in natura é a necessidade de corte diário, já que o material colhido e triturado fermenta-se rapidamente se não for consumido logo em seguida, reduzindo sua palatabilidade (Kung Jr. e Stanley, 1982). A ensilagem da cana-de-açúcar poderia contornar esse problema (Kung Jr. e Stanley, 1982), permitindo a racionalização dos custos de mão-de-obra, por meio da concentração do processo de corte da cana em uma determinada época do ano, a maior facilidade de manejo diário na fazenda e a maximização da utilização do maquinário (Castro Neto, 2003).

Aditivos químicos e inoculantes microbianos têm sido utilizados com o intuito de melhorar o padrão de fermentação e conservação das silagens, promovendo o desenvolvimento dos microrganismos benéficos, como as bactérias produtoras de ácido lático, e a inibição dos indesejáveis, como as leveduras e clostrídios. Apesar da crescente demanda de informações sobre a ensilagem de cana-de-açúcar, observa-se reduzido desenvolvimento científico em relação ao uso de aditivos que proporcionem diminuição das perdas de matéria seca e valor nutritivo da forragem ensilada (Pedroso, 2003). O objetivo deste trabalho foi estudar as características de fermentação das silagens de cana-de-açúcar, variedade RB72454, sem tratamento ou tratada com uréia, zeólita, uréia e zeólita, inoculante bacteriano comercial e inoculante bacteriano/enzimático comercial .

\section{MATERIAL E MÉTODOS}

A cana-de-açúcar, variedade RB72454, plantada em agosto de 2000, em dois canteiros (repetições), foi o objeto deste experimento. A adubação de cobertura foi realizada utilizando-se $350 \mathrm{~kg} / \mathrm{ha}$ de N:P:K (20-05-20), parcelada em três aplicações. Os canteiros foram irrigados durante todo o período de desenvolvimento da cana-deaçúcar. A colheita foi realizada em março de 2001. No momento da ensilagem, a cana-deaçúcar foi submetida aos seguintes tratamentos, em porcentagem da matéria verde: 1) Sem aditivo (testemunha); 2) Tratada com $0,5 \%$ de uréia (comercial granulada); 3) Tratada com $0,5 \%$ de zeólita; 4) Tratada com $0,5 \%$ de uréia + $0,5 \%$ de zeólita; 5) Tratada com inoculante 
bacteriano $^{1}$; 6) Tratada com inoculante bacteriano/enzimático ${ }^{2}$.

A forragem fresca foi picada em partículas de, aproximadamente, $1,5 \mathrm{~cm}$, homogeneizada e amostrada como material não ensilado (material original). $\mathrm{O}$ restante foi submetido aos tratamentos pré-determinados. A uréia e a zeólita foram adicionadas secas e os inoculantes comerciais foram preparados pouco antes do momento da adição à forragem, seguindo as recomendações dos fabricantes. A forragem foi ensilada em silos experimentais de poli-cloreto de vinila (PVC). Utilizaram-se três réplicas, seis aditivos e duas repetições, por aditivo, para cada dia de abertura dos silos, totalizando 252 silos.

O material original foi pré-seco em estufa de ventilação forçada, a $65^{\circ} \mathrm{C}$, por 72 horas, para determinação da matéria pré-seca (Official..., 1995). Os silos foram abertos com um, três, cinco, sete, 14, 28, e 56 dias após a ensilagem, sendo divididos em três partes. A primeira foi utilizada para extração do suco da silagem, a segunda foi utilizada para determinação da matéria pré-seca (Official..., 1995) e a última parte foi congelada, servindo como contraprova experimental.

Para análise do nitrogênio amoniacal, por meio da destilação com cloreto de cálcio e óxido de magnésio, utilizando-se o ácido bórico como solução receptora e o ácido clorídrico para a titulação e a determinação do $\mathrm{pH}$, o suco das silagens foi utilizado imediatamente após sua extração. $O$ teor de nitrogênio amoniacal foi inicialmente expresso em miligramas por $100 \mathrm{ml}$ de suco de silagem $\left(\mathrm{N}-\mathrm{NH}_{3}\right.$, em $\left.\mathrm{mg} \%\right)$. Após as análises de matéria seca e proteína bruta, o nitrogênio amoniacal foi expresso como porcentagem do nitrogênio total $\left(\mathrm{N}-\mathrm{NH}_{3} / \mathrm{NT}\right.$.

No material pré-seco e moído, determinaram-se os teores de matéria seca em estufa a $105^{\circ} \mathrm{C}$ (Official..., 1995), de proteína bruta, pelo método Kjeldhal (Official..., 1995), dos componentes da parede celular (fibra em detergente neutro, fibra em detergente ácido, hemicelulose, celulose e lignina em ácido sulfúrico), por meio do método seqüencial (Van Soest et al., 1991), dos carboidratos solúveis (Bailey, 1967, adaptada por

${ }^{1}$ Silobac ${ }^{\circledR}$ - CHR Hansen Ind. Com. - Valinhos, SP - Brasil ${ }^{2}$ BioMax ${ }^{\circledR}$ - CHR Hansen Ind. Com. - Valinhos, SP - Brasil
Valadares Filho, 1981) e os valores de digestibilidade in vitro da matéria seca (Tilley e Terry, 1963).

O delineamento estatístico foi o de parcelas subdivididas, com seis tratamentos (parcelas), duas repetições (blocos) e sete dias de abertura (subparcelas). Para comparação das médias, utilizou-se $\mathrm{o}$ teste SNK $(\mathrm{P}<0,05)$. Foram realizadas correlações de Pearson entre as variáveis. Os dados foram analisados pelo programa estatístico SAEG (Sistema..., 1997).

\section{RESULTADOS E DISCUSSÃO}

A composição bromatológica percentual e a digestibilidade in vitro da matéria seca (DIVMS) do material original (MO) e da silagem da canade-açúcar encontram-se na Tab. 1. O conteúdo de matéria seca (MS) da cana-de-açúcar foi de $28,2 \%$, semelhante ao encontrado por Alli e Baker (1982) que foi de $28,2 \%$ para a cana-deaçúcar, variedade B41227, também colhida aos sete meses de crescimento. O conteúdo de MS da cana-de-açúcar varia de acordo com a variedade (Peixoto, 1986; Landell et al., 2002) e com a idade da planta (Kung Jr. e Stanley, 1982). A partir do $28^{\circ}$ dia de fermentação, observa-se redução do conteúdo de MS da silagem. Alli e Baker (1982) observaram redução do conteúdo de MS na silagem de cana-de-açúcar (B41227), de $28,2 \%$ para $22,9 \%$, com 10 dias de fermentação. A concentração de proteína bruta (PB) encontrada no MO foi de 2,2\%. Durante o processo fermentativo, não houve variação da concentração de PB na silagem testemunha. Alli et al. (1983) também não observaram variação da concentração de PB com a ensilagem da cana-deaçúcar, que foi de 2,5\% com zero e 42 dias de fermentação.

A concentração de FDN no $\mathrm{MO}$ foi de 55,3\%. Rodrigues et al. (2001) avaliaram a qualidade de 18 variedades de cana-de-açúcar, colhidas aos 12 meses de crescimento, e verificaram que o conteúdo de FDN variou entre $44,2 \%$ e $56,4 \%$. Houve aumento da concentração de FDN na silagem a partir do $7^{\circ}$ dia de fermentação. Alcântara et al. (1989) também observaram aumento do teor de FDN na silagem de cana-deaçúcar $(67,5 \%)$ em relação ao material original $(50,2 \%)$. A concentração de fibra detergente ácido (FDA) no MO foi de 32,3\%. Oliveira et al. 
(1998) observaram que as concentrações de FDA de diferentes variedades de cana-de-açúcar variaram entre $27,5 \%$ e $35,5 \%$. A partir do $14^{\circ}$ dia de fermentação, observa-se aumento da concentração de FDA na silagem, em relação ao
MO. Pedroso (2003) encontrou uma concentração de FDA de $45,0 \%$ na silagem de cana-de-açúcar (RB835486) com 45 dias de fermentação, ensilada aos 12 meses de idade.

Tabela 1. Composição bromatológica percentual e digestibilidade in vitro da matéria seca (DIVMS) do material original (MO) e da silagem da cana-de-açúcar, variedade RB72454, colhida aos sete meses de crescimento

\begin{tabular}{lcccccccc}
\hline & \multicolumn{7}{c}{ Dias de ensilagem } \\
\cline { 2 - 8 } & MO & 1 & 3 & 5 & 7 & 14 & 28 & 56 \\
\hline MS & $28,16 \mathrm{a}$ & $28,71 \mathrm{a}$ & $28,01 \mathrm{a}$ & $27,18 \mathrm{a}$ & $26,32 \mathrm{a}$ & $24,71 \mathrm{ab}$ & $22,94 \mathrm{~b}$ & $21,58 \mathrm{~b}$ \\
PB $^{1}$ & $2,2 \mathrm{a}$ & $2,43 \mathrm{a}$ & $2,33 \mathrm{a}$ & $2,48 \mathrm{a}$ & $2,41 \mathrm{a}$ & $2,72 \mathrm{a}$ & $2,77 \mathrm{a}$ & $2,99 \mathrm{a}$ \\
FDN $^{1}$ & $55,27 \mathrm{c}$ & $54,68 \mathrm{c}$ & $55,99 \mathrm{c}$ & $54,16 \mathrm{c}$ & $61,48 \mathrm{~b}$ & $67,01 \mathrm{a}$ & $68,38 \mathrm{a}$ & $69,65 \mathrm{a}$ \\
FDA $^{1}$ & $32,43 \mathrm{bc}$ & $31,84 \mathrm{bc}$ & $32,69 \mathrm{bc}$ & $30,65 \mathrm{c}$ & $35,37 \mathrm{~b}$ & $39,40 \mathrm{a}$ & $40,80 \mathrm{a}$ & $39,59 \mathrm{a}$ \\
CHOS $^{1}$ & $21,46 \mathrm{a}$ & $22,62 \mathrm{a}$ & $15,22 \mathrm{ab}$ & $13,64 \mathrm{ab}$ & $9,03 \mathrm{bc}$ & $3,31 \mathrm{c}$ & $4,67 \mathrm{c}$ & $0,74 \mathrm{c}$ \\
DIVMS $^{1}$ & $58,13 \mathrm{a}$ & $57,65 \mathrm{a}$ & $58,85 \mathrm{a}$ & $57,45 \mathrm{a}$ & $54,48 \mathrm{a}$ & $48,63 \mathrm{~b}$ & $45,90 \mathrm{~b}$ & $46,48 \mathrm{~b}$ \\
\hline
\end{tabular}

$\mathrm{MS}=$ matéria seca $(\mathrm{CV}=4,4 \%) ; \mathrm{PB}=$ proteína bruta $(\mathrm{CV}=12,3 \%) ; \mathrm{FDN}=$ fibra detergente neutro $(\mathrm{CV}=3,2 \%) ; \mathrm{FDA}=$ fibra detergente ácido $(\mathrm{CV}=3,7 \%)$; $\mathrm{CHOS}=$ carboidratos solúveis $(\mathrm{CV}=4,4 \%)$; DIVMS= digestibilidade in vitro da matéria seca $(\mathrm{CV}=3,5 \%)$

${ }^{1}$ Dados expressos em porcentagem de MS

Médias seguidas de letras distintas na linha diferem entre si pelo teste $\mathrm{SNK}(\mathrm{P}<0,05)$

A cana-de-açúcar (MO) apresentou uma concentração de carboidratos solúveis (CHOS) em etanol de 21,46\%. Pedroso (2003) observou um conteúdo de CHOS em água em torno de 23,0\% na cana-de-açúcar, variedade RB835486, colhida aos 12 meses de crescimento. Rodrigues et al. (2001) relataram que o conteúdo de sacarose de 18 variedades de cana-de-açúcar variou de $13,72 \%$ a $15,60 \%$. Há uma variação na composição química da cana-de-açúcar de acordo com a variedade e a idade de colheita (Peixoto, 1986), entretanto a comparação dos resultados de conteúdo de CHOS deve ser ainda mais criteriosa devido às diferentes metodologias utilizadas pelos pesquisadores para sua determinação. Observa-se redução significativa da concentração de CHOS ao longo do processo fermentativo. Pedroso (2003) relatou uma redução da concentração de CHOS em água, que foi de $23 \%$, às 12 horas, e $6,83 \%$ aos 45 dias de fermentação.

$\mathrm{O}$ coeficiente de digestibilidade in vitro da matéria seca (DIVMS) do MO foi de 58,13\%. Kung Jr. e Stanley (1982) observaram um aumento da DIVMS da cana-de-açúcar, com o avanço da idade, de 52,60\%, aos seis meses, e $60,30 \%$, aos 24 meses de idade. Segundo Banda e Valdez (1976), o aumento da DIVMS da cana com o avanço da maturidade ocorre devido ao aumento do conteúdo de açúcares solúveis e redução percentual dos constituintes de parede celular. A redução do coeficiente de DIVMS, durante a fermentação, refletiu o aumento da concentração de MS, FDN e FDA da silagem.

Os teores de MS das silagens de cana-de-açúcar são apresentados na Tab. 2. Observa-se que, em todos os dias de abertura dos silos, não houve diferença significativa nos teores de MS entre a silagem testemunha e aquelas submetidas aos diferentes tratamentos. Em relação ao $1^{\circ}$ dia de fermentação, observa-se uma redução significativa nos teores de MS a partir do $14^{\circ}$ dia para as silagens tratadas com zeólita e inoculante bacteriano/enzimático e do $28^{\circ}$ dia para as silagens tratadas com uréia, uréia+zeólita e inoculante bacteriano. Alli e Baker (1982) observaram redução nos teores de MS na silagem de cana-de-açúcar (B41227), de 28,2\% para 22,9\%, com 10 dias de fermentação, justificando essa redução a partir da evaporação do dióxido de carbono e etanol, os quais foram produzidos pelas leveduras durante o processo fermentativo da silagem. 
Tabela 2. Concentração de matéria seca das silagens de cana-de-açúcar (RB72454), submetidas a diferentes tratamentos e avaliadas em diferentes dias após a ensilagem, expressas em porcentagem

\begin{tabular}{lccccccc}
\hline \multirow{2}{*}{ Tratamento } & \multicolumn{7}{c}{ Dias de ensilagem } \\
\cline { 2 - 7 } & 1 & 3 & 5 & 7 & 14 & 28 & 56 \\
\hline Testemunha & $27,94 \mathrm{Aa}$ & $28,01 \mathrm{Aa}$ & $27,18 \mathrm{Aa}$ & $26,33 \mathrm{ABa}$ & $24,71 \mathrm{ABCa}$ & $22,94 \mathrm{BCa}$ & $21,58 \mathrm{Ca}$ \\
Uréia & $27,77 \mathrm{Aa}$ & $26,86 \mathrm{Aa}$ & $25,13 \mathrm{ABa}$ & $25,58 \mathrm{ABa}$ & $23,89 \mathrm{ABa}$ & $22,17 \mathrm{Ba}$ & $21,56 \mathrm{Ba}$ \\
Zeólita & $28,91 \mathrm{Aa}$ & $27,27 \mathrm{ABa}$ & $27,24 \mathrm{ABa}$ & $26,35 \mathrm{ABa}$ & $23,36 \mathrm{BCa}$ & $23,22 \mathrm{BCa}$ & $20,44 \mathrm{Ca}$ \\
Uréia/zeólita & $28,80 \mathrm{Aa}$ & $27,69 \mathrm{ABa}$ & $28,00 \mathrm{ABa}$ & $28,20 \mathrm{ABa}$ & $25,19 \mathrm{ABCa}$ & $24,22 \mathrm{BCa}$ & $22,86 \mathrm{Ca}$ \\
IB & $28,01 \mathrm{Aa}$ & $26,68 \mathrm{Aa}$ & $24,99 \mathrm{ABa}$ & $25,14 \mathrm{ABa}$ & $24,29 \mathrm{ABa}$ & $22,43 \mathrm{Ba}$ & $19,28 \mathrm{Ca}$ \\
IBE & $28,21 \mathrm{Aa}$ & $27,28 \mathrm{ABa}$ & $26,30 \mathrm{ABa}$ & $25,82 \mathrm{ABa}$ & $23,23 \mathrm{BCa}$ & $24,30 \mathrm{ABCa}$ & $20,91 \mathrm{Ca}$ \\
\hline
\end{tabular}

$\mathrm{IB}=$ inoculante bacteriano $\left(\right.$ Silobac $\left.{ }^{\circledR}\right) ; \mathrm{IBE}=$ inoculante bacteriano/enzimático (BioMax ${ }^{\circledR}$ cana).

Valores seguidos por letras distintas, maiúsculas na linha e minúsculas na coluna, diferem entre si pelo teste $\mathrm{SNK}(\mathrm{P}<0,05)$. $\mathrm{CV}=5,8 \%$

A concentração de carboidratos solúveis (CHOS) das silagens de cana-de-açúcar, variedade RB72454, encontra-se na Tab. 3. Diferenças significativas na concentração de CHOS, entre os diferentes tratamentos avaliados, foram observadas somente no $1^{\circ}$ e no $5^{\circ}$ dia após o início da fermentação. Ao longo do processo fermentativo, houve redução da concentração de CHOS em todas as silagens. Essa redução foi significativa a partir do $3^{\circ}$ dia para a silagem testemunha e a tratada com inoculante bacteriano/enzimático, e a partir do $5^{\circ}$ dia para as silagens tratadas com uréia, zeólita, uréia+zeólita e inoculante bacteriano.

Alli et al. (1983) observaram que a adição de $16,9 \mathrm{~kg}$ de amônia/t MS, no momento da ensilagem da cana-de-açúcar, promoveu uma menor perda de CHOS. Entretanto, no presente estudo, a amônia, proveniente da adição de uréia à silagem, não foi capaz de reduzir as perdas de CHOS, sendo que, ao final do período de fermentação, todos os tratamentos apresentaram um conteúdo de CHOS estatisticamente iguais.

Tabela 3. Concentração de carboidratos solúveis das silagens de cana-de-açúcar (RB72454), submetidas a diferentes tratamentos e avaliadas em diferentes dias após a ensilagem, expressas em porcentagem da matéria seca

\begin{tabular}{lccccccc}
\hline \multirow{2}{*}{ Tratamento } & \multicolumn{7}{c}{ Dias de ensilagem } \\
\cline { 2 - 7 } & 1 & 2 & 5 & 7 & 14 & 28 & 56 \\
\hline Testemunha & $22,62 \mathrm{Aab}$ & $15,22 \mathrm{Ba}$ & $13,64 \mathrm{BCa}$ & $9,03 \mathrm{CDa}$ & $3,31 \mathrm{DEa}$ & $4,67 \mathrm{DEa}$ & $0,74 \mathrm{Ea}$ \\
Uréia & $16,38 \mathrm{Ab}$ & $13,19 \mathrm{Aa}$ & $6,32 \mathrm{Bbc}$ & $7,09 \mathrm{Ba}$ & $2,51 \mathrm{Ba}$ & $3,51 \mathrm{Ba}$ & $0,82 \mathrm{Ba}$ \\
Zeólita & $19,21 \mathrm{Aab}$ & $14,86 \mathrm{ABa}$ & $10,54 \mathrm{BCab}$ & $8,86 \mathrm{Ca}$ & $4,98 \mathrm{CDa}$ & $5,12 \mathrm{CDa}$ & $0,78 \mathrm{Da}$ \\
Uréia/zeólita & $16,37 \mathrm{Aab}$ & $14,38 \mathrm{Aa}$ & $3,57 \mathrm{Bc}$ & $4,58 \mathrm{Ba}$ & $1,89 \mathrm{Ba}$ & $3,36 \mathrm{Ba}$ & $1,09 \mathrm{Ba}$ \\
IB & $21,44 \mathrm{Aab}$ & $16,97 \mathrm{Aa}$ & $8,92 \mathrm{Babc}$ & $10,08 \mathrm{Ba}$ & $6,71 \mathrm{BCa}$ & $4,81 \mathrm{BCa}$ & $0,94 \mathrm{Ca}$ \\
IBE & $23,34 \mathrm{Aa}$ & $14,05 \mathrm{Ba}$ & $13,91 \mathrm{Ba}$ & $8,86 \mathrm{BCa}$ & $8,01 \mathrm{BCa}$ & $6,17 \mathrm{Ca}$ & $1,15 \mathrm{Da}$ \\
\hline
\end{tabular}

$\mathrm{IB}=$ inoculante bacteriano $\left(\right.$ Silobac $\left.{ }^{\circledR}\right) ; \mathrm{IBE}=$ inoculante bacteriano/enzimático (BioMax ${ }^{\circledR}$ cana).

Valores seguidos por letras distintas, maiúsculas na linha e minúsculas na coluna, diferem entre si pelo teste $\mathrm{SNK}(\mathrm{P}<0,05)$. $\mathrm{CV}=27,2 \%$

Castro Neto (2003) avaliou os mesmos aditivos utilizados neste experimento para a ensilagem da cana-de-açúcar e também observou que nenhum deles foi capaz de minimizar a redução do conteúdo de CHOS da cana durante o processo fermentativo. O uso do inoculante bacteriano e inoculante bacteriano/enzimático não foi eficaz para inibir o uso dos CHOS da cana-de-açúcar durante o processo fermentativo. É importante ressaltar que o sucesso do uso de inoculantes bacterianos depende de vários fatores, dentre eles o número de bactérias viáveis existentes no produto e o número de microrganismos pertencentes à flora epífita, isto é, presentes na própria planta. Como decorrência, observa-se uma grande variação entre os resultados de experimentos que avaliam o uso de inoculantes bacterianos nas silagens de diferentes forrageiras.

$\mathrm{Na}$ Tab. 4 são mostradas as concentrações de proteína bruta $(\mathrm{PB})$ e nitrogênio amoniacal em relação ao nitrogênio total $\left(\% \mathrm{~N}^{-\mathrm{NH}_{3}} / \mathrm{NT}\right)$ das silagens de cana-de-açúcar. As silagens que receberam uréia e uréia+zeólita apresentaram maiores concentrações de $\mathrm{PB}$ em todos os períodos de fermentação. As concentrações de PB da silagem testemunha e daquelas tratadas 
com zeólita, inoculante bacteriano e inoculante bacteriano/enzimático variaram entre $2,11 \% \mathrm{e}$ $3,09 \%$, resultado esperado devido ao baixo teor de $\mathrm{PB}$ da cana-de-açúcar observado no MO, que foi em média 2,20\%. Durante o processo fermentativo, não houve variação da concentração de PB na silagem testemunha. Alli et al. (1983) igualmente não observaram variação do conteúdo de $\mathrm{PB}$ na silagem da cana-deaçúcar, que foi de 2,50\% com zero e 42 dias de fermentação.

Tabela 4. Concentração de proteína bruta $(\mathrm{N}$ x 6,25) e nitrogênio amoniacal em relação ao nitrogênio total das silagens de cana-de-açúcar (RB72454), submetidas a diferentes tratamentos e avaliadas em diferentes dias após a ensilagem, expressas em porcentagem da matéria seca

\begin{tabular}{lccccccc}
\hline & \multicolumn{7}{c}{ Dias de ensilagem } \\
\cline { 2 - 7 } & 1 & 3 & 5 & 7 & 14 & 28 & 56 \\
\hline PB & & & & & & & \\
Testemunha & $2,43 \mathrm{Ac}$ & $2,33 \mathrm{Ab}$ & $2,48 \mathrm{Ac}$ & $2,41 \mathrm{Ab}$ & $2,72 \mathrm{Ac}$ & $2,77 \mathrm{Ab}$ & $2,99 \mathrm{Ab}$ \\
Uréia & $7,91 \mathrm{Aa}$ & $6,45 \mathrm{Ca}$ & $7,24 \mathrm{Ba}$ & $6,98 \mathrm{Ba}$ & $7,98 \mathrm{Aa}$ & $8,21 \mathrm{Aa}$ & $8,39 \mathrm{Aa}$ \\
Zeólita & $2,39 \mathrm{ABc}$ & $2,12 \mathrm{Bb}$ & $2,11 \mathrm{Bc}$ & $2,40 \mathrm{ABb}$ & $2,59 \mathrm{ABc}$ & $2,67 \mathrm{ABb}$ & $2,99 \mathrm{Ab}$ \\
Uréia/zeólita & $6,91 \mathrm{Cb}$ & $6,78 \mathrm{Ca}$ & $6,41 \mathrm{Cb}$ & $6,74 \mathrm{Ca}$ & $7,49 \mathrm{Bb}$ & $7,91 \mathrm{Ba}$ & $8,45 \mathrm{Aa}$ \\
$\mathrm{IB}$ & $2,51 \mathrm{Bc}$ & $2,19 \mathrm{Bb}$ & $2,19 \mathrm{Bc}$ & $2,29 \mathrm{Bb}$ & $2,44 \mathrm{Bc}$ & $2,57 \mathrm{Bb}$ & $3,09 \mathrm{Ab}$ \\
$\mathrm{IBE}$ & $2,39 \mathrm{ABc}$ & $2,45 \mathrm{ABb}$ & $2,13 \mathrm{Bc}$ & $2,58 \mathrm{ABb}$ & $2,62 \mathrm{ABc}$ & $2,51 \mathrm{ABb}$ & $2,99 \mathrm{Ab}$ \\
\hline $\mathrm{NNH} / \mathrm{NT}$ & & & & & & & \\
Testemunha & $3,94 \mathrm{Ab}$ & $2,45 \mathrm{Ab}$ & $3,66 \mathrm{Ab}$ & $6,75 \mathrm{Ab}$ & $5,57 \mathrm{Ab}$ & $6,25 \mathrm{Ab}$ & $4,35 \mathrm{Ab}$ \\
Uréia & $13,43 \mathrm{Ca}$ & $20,17 \mathrm{Ba}$ & $23,69 \mathrm{ABa}$ & $23,67 \mathrm{ABa}$ & $25,35 \mathrm{ABa}$ & $29,93 \mathrm{Aa}$ & $30,42 \mathrm{Aa}$ \\
Zeólita & $5,51 \mathrm{Ab}$ & $3,80 \mathrm{Ab}$ & $4,36 \mathrm{Ab}$ & $3,57 \mathrm{Ab}$ & $5,10 \mathrm{Ab}$ & $5,07 \mathrm{Ab}$ & $5,50 \mathrm{Ab}$ \\
Uréia/zeólita & $12,30 \mathrm{Ca}$ & $21,93 \mathrm{Ba}$ & $24,39 \mathrm{ABa}$ & $27,65 \mathrm{ABa}$ & $30,52 \mathrm{Aa}$ & $32,93 \mathrm{Aa}$ & $31,09 \mathrm{Aa}$ \\
IB & $1,78 \mathrm{Ab}$ & $2,97 \mathrm{Ab}$ & $2,91 \mathrm{Ab}$ & $3,16 \mathrm{Ab}$ & $3,26 \mathrm{Ab}$ & $3,40 \mathrm{Ab}$ & $3,81 \mathrm{Ab}$ \\
IBE & $2,89 \mathrm{Ab}$ & $2,36 \mathrm{Ab}$ & $3,13 \mathrm{Ab}$ & $3,12 \mathrm{Ab}$ & $3,54 \mathrm{Ab}$ & $4,73 \mathrm{Ab}$ & $6,09 \mathrm{Ab}$ \\
\hline
\end{tabular}

$\mathrm{IB}=$ inoculante bacteriano $\left(\right.$ Silobac $\left.{ }^{\circledR}\right) ; \mathrm{IBE}=$ inoculante bacteriano/enzimático (BioMax ${ }^{\circledR}$ cana).

Valores seguidos por letras distintas, maiúsculas na linha e minúsculas na coluna, diferem entre si pelo teste $\mathrm{SNK}(\mathrm{P}<0,05)$. $\mathrm{CV}(\mathrm{PB})=5,6 \% ; \mathrm{CV}\left(\mathrm{NNH}_{3} / \mathrm{NT}\right)=28,78 \%$.

As silagens tratadas com os diferentes aditivos apresentaram pequena variação nas concentrações de PB, principalmente no $56^{\circ}$ dia de abertura dos silos. Ao avaliar a dinâmica de fermentação da silagem de cana-de-açúcar, variedade RB835486, Pedroso (2003) observou um pequeno aumento da concentração média de PB a partir do $15^{\circ}$ dia pós-ensilagem. Molina et al. (1999) observaram que a inclusão de $1,1 \%$ de uréia à cana-de-açúcar, no momento da ensilagem, proporcionou um aumento da concentração média de $\mathrm{PB}$ da silagem de 1,6\% para $10,2 \%$. Neste trabalho, não houve diferença no conteúdo de $\mathrm{PB}$ entre a silagem testemunha e aquelas tratadas com inoculante bacteriano $\mathrm{e}$ inoculante bacteriano/enzimático, no $56^{\circ}$ dia de fermentação. Este resultado também foi observado por Pedroso (2003) ao avaliar a utilização de inoculantes microbianos contendo cepas de Lactobacillus plantarum (1x10 $\left.10^{6} \mathrm{uc} / \mathrm{gMV}\right) \quad$ e $\quad L . \quad$ buchneri $\left(3,64 \times 10^{5} \mathrm{ufc} / \mathrm{gMV}\right)$ na ensilagem da cana-deaçúcar.

Nota-se que as silagens tratadas com uréia e uréia + zeólita apresentaram maiores concentrações de N-
$\mathrm{NH}_{3} / \mathrm{NT}$, em todos os períodos de fermentação. $\mathrm{Na}$ silagem tratada com uréia, ocorreu aumento do teor de $\mathrm{N}-\mathrm{NH}_{3} / \mathrm{NT}$ no $3^{\circ}$ dia, acentuando-se a partir do $28^{\circ}$ dia de fermentação. Já na silagem tratada com uréia + zeólita, o teor de $\mathrm{N}-\mathrm{NH}_{3} / \mathrm{NT}$ aumentou a partir do $3^{\circ}$ dia, acentuando-se no $14^{\circ}$ dia de fermentação. A silagem testemunha e aquelas tratadas com zeólita, inoculante bacteriano e inoculante bacteriano/enzimático apresentaram teores de $\mathrm{N}_{-} \mathrm{NH}_{3} / \mathrm{NT}$ considerados baixos (inferiores a 10\%). Nessas silagens, a rápida ensilagem e adequada compactação e vedação dos silos de laboratório resultaram em baixa proteólise no material, produzindo silagens com baixas concentrações de N-NH$/ 2 / \mathrm{NT}$. O teor de $\mathrm{N}-\mathrm{NH}_{3} / \mathrm{NT}$ da silagem de cana-de-açúcar está de acordo com os teores encontrados em silagens produzidas com culturas tradicionais. Antunes (2001) avaliou o teor de $\mathrm{N}-\mathrm{NH}_{3} / \mathrm{NT}$ nas silagens de seis genótipos de milho (Zea mays L.) e observou um conteúdo médio de $6,17 \%$, aos 56 dias de fermentação. As concentrações de $\mathrm{N}-\mathrm{NH}_{3} / \mathrm{NT}$ das silagens tratadas com uréia e uréia+zeólita foram estatisticamente semelhantes $(\mathrm{P}>0,05)$ em todos os dias de abertura dos silos. Neste trabalho, a zeólita foi adicionada durante a ensilagem, juntamente com a uréia, com o objetivo de captar o excesso de amônia liberada, 
impedindo o incremento excessivo do $\mathrm{pH}$, prejudicial ao desenvolvimento das bactérias acidoláticas da silagem. Entretanto, os resultados indicam que a zeólita não foi eficiente em controlar a liberação de amônia, proveniente da hidrólise da uréia. Dessa forma, sua utilização não resultou em estímulo para o desenvolvimento das bactérias acido-láticas (Castro Neto, 2003).

Os valores de $\mathrm{pH}$, obtidos no suco das silagens de cana-de-açúcar, são apresentados na Tab. 5. Logo no $1^{\circ}$ dia de fermentação, todas as silagens avaliadas apresentaram um $\mathrm{pH}$ baixo, sendo estatisticamente iguais na silagem testemunha e nas silagens tratadas com zeólita, inoculante bacteriano e inoculante bacteriano/enzimático. A silagem tratada com uréia + zeólita apresentou, no $1^{\circ}$ dia pós-ensilagem, o maior valor médio de $\mathrm{pH}$, que foi de 4,18 , e a silagem tratada com uréia apresentou um pH intermediário, de 3,94, já que a uréia absorve íons $\mathrm{H}^{+}$presentes no meio, neutralizando- os, retardando, então, a redução do $\mathrm{pH}$ nessas silagens. A silagem testemunha apresentou valores de $\mathrm{pH}$ estáveis ao longo do processo fermentativo. As silagens que receberam aditivos apresentaram pequenas variações nos valores médios de $\mathrm{pH}$, com o avanço da fermentação, sendo que a silagem tratada com uréia+zeólita apresentou redução significativa dos valores de $\mathrm{pH}$ a partir do $3^{\circ}$ dia de fermentação. Entretanto, aos 56 dias após o início do processo fermentativo, todas as silagens estudadas apresentaram valores de $\mathrm{pH}$ estatisticamente iguais $(\mathrm{P}>0,05)$, considerados adequados para a preservação da silagem. Segundo McDonald et al. (1991), silagens de boa qualidade apresentam valores de $\mathrm{pH}$ entre 3,6 e 4,2. A preservação da cana-de-açúcar, por meio da ensilagem, é acompanhada por uma redução de $\mathrm{pH}$ (Preston et al., 1976), sendo um dos indicativos da baixa capacidade tamponante dessa forrageira (Alli e Baker, 1982).

Tabela 5. Valores de $\mathrm{pH}$ dos sucos das silagens de cana-de-açúcar (RB72454), submetidas a diferentes tratamentos e avaliadas em diferentes dias após a ensilagem

\begin{tabular}{lccccccc}
\hline \multirow{2}{*}{ Tratamento } & \multicolumn{7}{c}{ Dias de ensilagem } \\
\cline { 2 - 8 } & 1 & 3 & 5 & 7 & 14 & 28 & 56 \\
\hline Testemunha & $3,42 \mathrm{Ac}$ & $3,55 \mathrm{Ab}$ & $3,51 \mathrm{Abc}$ & $3,47 \mathrm{Ab}$ & $3,36 \mathrm{Ab}$ & $3,42 \mathrm{Aab}$ & $3,43 \mathrm{Aa}$ \\
Uréia & $3,94 \mathrm{Ab}$ & $3,86 \mathrm{ABa}$ & $3,65 \mathrm{ABCab}$ & $3,71 \mathrm{ABCa}$ & $3,49 \mathrm{Cab}$ & $3,64 \mathrm{ABCa}$ & $3,63 \mathrm{ABCa}$ \\
Zeólita & $3,65 \mathrm{Ac}$ & $3,54 \mathrm{ABb}$ & $3,29 \mathrm{Bcd}$ & $3,41 \mathrm{ABb}$ & $3,36 \mathrm{ABb}$ & $3,34 \mathrm{ABa}$ & $3,51 \mathrm{ABa}$ \\
Uréia/zeólita & $4,18 \mathrm{Aa}$ & $3,86 \mathrm{Ba}$ & $3,78 \mathrm{Ba}$ & $3,85 \mathrm{Ba}$ & $3,68 \mathrm{Ba}$ & $3,67 \mathrm{Ba}$ & $3,70 \mathrm{Ba}$ \\
IB & $3,62 \mathrm{Ac}$ & $3,49 \mathrm{ABb}$ & $3,21 \mathrm{Bd}$ & $3,37 \mathrm{ABb}$ & $3,38 \mathrm{ABb}$ & $3,32 \mathrm{ABb}$ & $3,40 \mathrm{ABa}$ \\
IBE & $3,66 \mathrm{Ac}$ & $3,54 \mathrm{ABb}$ & $3,49 \mathrm{Abbc}$ & $3,46 \mathrm{ABb}$ & $3,39 \mathrm{ABb}$ & $3,32 \mathrm{Bb}$ & $3,43 \mathrm{ABa}$ \\
\hline
\end{tabular}

$\mathrm{IB}=$ inoculante bacteriano (Silobac $\mathbb{R}) ; \mathrm{IBE}=$ inoculante bacteriano/enzimático (BioMax $®$ cana).

Valores seguidos por letras distintas, maiúsculas na linha e minúsculas na coluna, diferem entre si pelo teste $\mathrm{SNK}(\mathrm{P}<0,05)$. $\mathrm{CV}=3,0 \%$.

As concentrações de fibra detergente neutro (FDN) e fibra detergente ácido (FDA) das silagens de cana-de-açúcar são vistas na Tab. 6 . Não houve diferença nos teores de FDN entre os tratamentos após um, três, cinco sete e 14 dias de fermentação. No $28^{\circ}$ dia, a silagem testemunha apresentou maior valor de FDN (68,38\%). No dia 56 , os maiores valores foram observados para as silagens tratadas com inoculante bacteriano e inoculante bacteriano/enzimático $\quad(72,22 \%$ e $70,75 \%$, respectivamente). Em todos os tratamentos avaliados, os teores de FDN aumentaram durante o processo fermentativo. $\mathrm{O}$ teor médio de FDN da silagem testemunha aumentou a partir do $7^{\circ}$ dia e estabilizou-se a partir do $14^{\circ}$ dia de ensilagem. Nas silagens tratadas com zeólita, inoculante bacteriano e inoculante bacteriano/enzimático, houve aumento significativo nos teores médios de FDN a partir do $7^{\circ}$ dia, e, no $14^{\circ}$ dia de fermentação, na silagem tratada com uréia e uréia + zeólita. $\mathrm{O}$ conteúdo de FDN esteve inversamente relacionado com o conteúdo de carboidratos solúveis $(\mathrm{r}=-0,77)$. Ao longo do processo fermentativo, há uma redução do conteúdo de carboidratos solúveis, utilizados pelos microrganismos presentes na silagem e, conseqüentemente, redução do conteúdo de matéria seca $(\mathrm{r}=0,69)$, provocando um aumento percentual dos constituintes da parede celular não utilizados na silagem. Pedroso (2003), ao avaliar parâmetros fermentativos da silagem de cana-de-açúcar sem aditivos, observou, também, uma relação inversa entre carboidratos solúveis e perdas de matéria seca $(\mathrm{r}=-0,96)$ e, ainda, entre carboidratos solúveis e FDN $(\mathrm{r}=-0,97)$. 
Tabela 6. Concentrações de fibra detergente neutro (FDN) e fibra detergente ácido (FDA) das silagens de cana-de-açúcar (RB72454), submetidas a diferentes tratamentos e avaliadas em diferentes dias após a ensilagem, expressas em porcentagem da matéria seca

\begin{tabular}{lccccccc}
\hline \multirow{2}{*}{ Tratamento } & \multicolumn{7}{c}{ Dias de ensilagem } \\
\cline { 2 - 7 } & 1 & 3 & 5 & 7 & 14 & 28 & 56 \\
\hline FDN & & & & & & \\
Testemunha & $54,68 \mathrm{Ca}$ & $55,99 \mathrm{Ca}$ & $54,16 \mathrm{Ca}$ & $61,48 \mathrm{Ba}$ & $67,01 \mathrm{Aa}$ & $68,38 \mathrm{Aa}$ & $69,65 \mathrm{Aab}$ \\
Uréia & $52,95 \mathrm{Ca}$ & $52,56 \mathrm{Ca}$ & $54,64 \mathrm{BCa}$ & $55,58 \mathrm{BCa}$ & $59,97 \mathrm{Ba}$ & $60,99 \mathrm{Bb}$ & $66,29 \mathrm{Aab}$ \\
Zeólita & $51,81 \mathrm{Ca}$ & $52,73 \mathrm{Ca}$ & $53,86 \mathrm{Ca}$ & $59,80 \mathrm{Ba}$ & $64,33 \mathrm{ABa}$ & $65,26 \mathrm{ABab}$ & $69,49 \mathrm{Aab}$ \\
Uréia/zeólita & $54,56 \mathrm{Ba}$ & $54,66 \mathrm{Ba}$ & $53,98 \mathrm{Ba}$ & $55,79 \mathrm{Ba}$ & $63,42 \mathrm{Aa}$ & $61,64 \mathrm{Ab}$ & $63,46 \mathrm{Ab}$ \\
IB & $52,71 \mathrm{Ca}$ & $53,75 \mathrm{Ca}$ & $57,62 \mathrm{BCa}$ & $59,96 \mathrm{Ba}$ & $60,91 \mathrm{Ba}$ & $64,05 \mathrm{Bab}$ & $72,22 \mathrm{Aa}$ \\
IBE & $51,17 \mathrm{Ca}$ & $52,54 \mathrm{Ca}$ & $51,36 \mathrm{Ca}$ & $60,07 \mathrm{Ba}$ & $60,25 \mathrm{Ba}$ & $59,27 \mathrm{Bb}$ & $70,75 \mathrm{Aa}$ \\
\hline FDA & & & & & & & \\
\hline Testemunha & $31,84 \mathrm{BCa}$ & $32,69 \mathrm{BCa}$ & $30,65 \mathrm{Ca}$ & $35,37 \mathrm{Ba}$ & $39,40 \mathrm{Aa}$ & $40,80 \mathrm{Aa}$ & $39,59 \mathrm{Aab}$ \\
Uréia & $31,27 \mathrm{BCa}$ & $30,66 \mathrm{Ca}$ & $31,32 \mathrm{Ca}$ & $31,35 \mathrm{Ca}$ & $35,08 \mathrm{Ba}$ & $36,04 \mathrm{ABab}$ & $39,67 \mathrm{Aab}$ \\
Zeólita & $29,92 \mathrm{Ca}$ & $30,72 \mathrm{BCa}$ & $31,76 \mathrm{BCa}$ & $34,83 \mathrm{Ba}$ & $38,97 \mathrm{Aa}$ & $39,09 \mathrm{Aab}$ & $40,14 \mathrm{Aab}$ \\
Uréia/zeólita & $31,71 \mathrm{Ba}$ & $32,44 \mathrm{Ba}$ & $31,52 \mathrm{Ba}$ & $32,36 \mathrm{Ba}$ & $38,19 \mathrm{Aa}$ & $36,87 \mathrm{Aab}$ & $36,25 \mathrm{Ab}$ \\
IB & $31,18 \mathrm{Ba}$ & $30,94 \mathrm{Ba}$ & $33,52 \mathrm{Ba}$ & $35,50 \mathrm{Ba}$ & $35,68 \mathrm{Ba}$ & $39,22 \mathrm{Aab}$ & $41,72 \mathrm{Aa}$ \\
IBE & $29,98 \mathrm{Ca}$ & $29,97 \mathrm{Ca}$ & $29,62 \mathrm{Ca}$ & $35,72 \mathrm{Ba}$ & $35,91 \mathrm{Ba}$ & $34,81 \mathrm{Bb}$ & $40,36 \mathrm{Aab}$ \\
\hline
\end{tabular}

$\mathrm{IB}=$ inoculante bacteriano $\left(\right.$ Silobac $\left.{ }^{\circledR}\right) ; \mathrm{IBE}=$ inoculante bacteriano/enzimático (BioMax ${ }^{\circledR}$ cana).

Valores seguidos por letras distintas, maiúsculas na linha e minúsculas na coluna, diferem entre si pelo teste $\mathrm{SNK}(\mathrm{P}<0,05)$. $\mathrm{CV}(\mathrm{FDN})=4,2 \% ; \mathrm{CV}(\mathrm{FDA})=4,9 \%$.

Entre os tratamentos, foram verificadas diferenças nas concentrações de FDA a partir do $28^{\circ}$ dia de fermentação. O maior valor de FDA, no $28^{\circ}$ dia, foi observado na silagem testemunha e, no $56^{\circ}$ dia de fermentação, foi observado na silagem tratada com inoculante bacteriano. As concentrações de FDA aumentaram com o avanço do processo fermentativo em todos os tratamentos avaliados. Esse aumento foi significativo a partir do $7^{\circ}$ dia para a silagem tratada com inoculante bacteriano/enzimático; no $14^{\circ}$ dia, para a silagem testemunha e aquelas tratadas com uréia, zeólita, uréia + zeólita e, somente no $28^{\circ}$ dia, para a silagem tratada com inoculante bacteriano. A silagem de cana-deaçúcar apresentou concentração de FDA médio de 43,1\% com 10 dias de ensilagem (Alli e Baker, 1982). Kung Jr. e Stanley (1982) observaram concentrações de FDA de $43,4 \%$ e $45,6 \%$ nas silagens de cana-de-açúcar ensiladas aos seis e nove meses de idade, respectivamente. Alli et al. (1983) observaram aumento das concentrações de FDA após a ensilagem da canade-açúcar.

Na Tab. 7 são demonstradas as concentrações de celulose, hemicelulose e lignina das silagens de cana-de-açúcar. Foram verificadas diferenças nas concentrações de celulose entre os tratamentos somente a partir do $28^{\circ}$ dia de ensilagem. No $28^{\circ}$ dia, a silagem testemunha apresentou maior concentração média de celulose $(35,87 \%)$, porém não diferiu $(\mathrm{p}>0,05)$ da concentração de celulose das silagens tratadas com uréia, zeólita, uréia+zeólita e inoculante bacteriano. No $56^{\circ}$ dia de fermentação, a maior concentração de celulose foi encontrada na silagem tratada com inoculante bacteriano $(36,57 \%)$, porém não diferiu $(\mathrm{P}>0,05)$ da concentração de celulose das silagens testemunha e tratadas com uréia, zeólita e inoculante bacteriano/enzimático.

Ao longo do processo fermentativo, houve aumento das concentrações de celulose, acentuando-se a partir do $14^{\circ}$ dia, na silagem testemunha e tratadas com uréia, zeólita e uréia +zeólita. Nas silagens tratadas com inoculante bacteriano e inoculante bacteriano/enzimático, esse aumento ocorreu a partir do $28^{\circ}$ dia. Avaliando as silagens de cana-de-açúcar colhidas em diferentes idades, Kung Jr. e Stanley (1982) observaram concentrações de celulose de $33 \%$ e $34 \%$ nas silagens obtidas a partir da cana-deaçúcar colhida com seis e nove meses de idade, respectivamente. Um aumento nas concentrações de celulose na silagem de cana-de-açúcar também foi encontrado por Alcântara et al. (1989), sendo de $27,5 \%$ no material original e $34,2 \%$ na silagem com 30 dias de fermentação. Ao avaliar a concentração de celulose na silagem de Lolium perenne, Morrison (1979) observou aumento desse constituinte quando calculado em relação à matéria seca da silagem. Entretanto, ao avaliar a quantidade de celulose da silagem em 
relação à quantidade original (valores absolutos), o pesquisador observou que não houve variação. $\mathrm{O}$ aumento da concentração de celulose observado neste experimento ao longo do período fermentativo parece ser decorrente de uma redução proporcional do conteúdo de carboidratos solúveis e, conseqüentemente, de matéria seca. Segundo Castro Neto (2003), a fermentação dos carboidratos solúveis por diferentes microrganismos (bactérias ácidoláticas e leveduras) presentes na silagem pode provocar extensas perdas de matéria seca, justificando o aumento proporcional da fração fibrosa.

Tabela 7. Concentração de celulose, hemicelulose e lignina das silagens de cana-de-açúcar (RB72454), submetidas a diferentes tratamentos e avaliadas em diferentes dias após a ensilagem, expressas em porcentagem da matéria seca

\begin{tabular}{lccccccc}
\hline \multirow{2}{*}{ Tratamento } & \multicolumn{7}{c}{ Dias de ensilagem } \\
\cline { 2 - 8 } Celulose & 1 & 3 & 5 & 7 & 14 & 28 & 56 \\
Testemunha & $27,12 \mathrm{Da}$ & $28,34 \mathrm{CDa}$ & $26,83 \mathrm{Da}$ & $31,29 \mathrm{BCa}$ & $34,46 \mathrm{ABa}$ & $35,87 \mathrm{Aa}$ & $34,53 \mathrm{ABab}$ \\
Uréia & $26,36 \mathrm{Ca}$ & $26,01 \mathrm{Ca}$ & $28,06 \mathrm{BCa}$ & $28,11 \mathrm{BCa}$ & $30,95 \mathrm{ABa}$ & $31,33 \mathrm{ABb}$ & $34,19 \mathrm{Aab}$ \\
Zeólita & $25,98 \mathrm{Ca}$ & $26,21 \mathrm{Ca}$ & $27,55 \mathrm{Ca}$ & $30,63 \mathrm{Ba}$ & $34,19 \mathrm{ABa}$ & $33,56 \mathrm{ABab}$ & $34,91 \mathrm{Aab}$ \\
Uréia/zeólita & $26,94 \mathrm{Ca}$ & $27,55 \mathrm{Ca}$ & $27,56 \mathrm{Ca}$ & $29,04 \mathrm{BCa}$ & $33,53 \mathrm{Aa}$ & $32,09 \mathrm{ABab}$ & $31,70 \mathrm{ABb}$ \\
IB & $26,99 \mathrm{Da}$ & $27,41 \mathrm{Da}$ & $29,58 \mathrm{CDa}$ & $30,58 \mathrm{BCDa}$ & $31,55 \mathrm{BCa}$ & $33,84 \mathrm{ABab}$ & $36,57 \mathrm{Aa}$ \\
IBE & $25,23 \mathrm{Ca}$ & $26,25 \mathrm{Ca}$ & $25,83 \mathrm{Ca}$ & $30,75 \mathrm{Ba}$ & $31,62 \mathrm{Ba}$ & $30,51 \mathrm{Bb}$ & $35,35 \mathrm{Aab}$ \\
\hline Hemicelulose & & & & & & & \\
Testemunha & $22,84 \mathrm{Ca}$ & $23,29 \mathrm{Ca}$ & $23,50 \mathrm{Ca}$ & $25,27 \mathrm{BCa}$ & $27,61 \mathrm{Ba}$ & $27,58 \mathrm{ABa}$ & $30,06 \mathrm{Aa}$ \\
Uréia & $21,68 \mathrm{Ba}$ & $21,90 \mathrm{Ba}$ & $23,32 \mathrm{Ba}$ & $24,23 \mathrm{ABa}$ & $24,89 \mathrm{ABab}$ & $24,56 \mathrm{ABab}$ & $26,93 \mathrm{Ab}$ \\
Zeólita & $21,50 \mathrm{Ca}$ & $22,01 \mathrm{Ca}$ & $22,09 \mathrm{Ca}$ & $24,98 \mathrm{Ba}$ & $25,38 \mathrm{Bb}$ & $26,13 \mathrm{Bab}$ & $29,36 \mathrm{Aab}$ \\
Uréia/zeólita & $22,85 \mathrm{Ba}$ & $22,22 \mathrm{Ba}$ & $22,46 \mathrm{Ba}$ & $23,44 \mathrm{Ba}$ & $25,23 \mathrm{ABab}$ & $24,77 \mathrm{ABab}$ & $27,21 \mathrm{Ab}$ \\
IB & $21,52 \mathrm{Ca}$ & $22,88 \mathrm{BCa}$ & $24,09 \mathrm{BCa}$ & $24,46 \mathrm{Ba}$ & $25,23 \mathrm{Bab}$ & $24,84 \mathrm{Bb}$ & $30,49 \mathrm{Aa}$ \\
IBE & $21,19 \mathrm{Ca}$ & $22,57 \mathrm{BCa}$ & $21,74 \mathrm{BCa}$ & $24,35 \mathrm{Ba}$ & $24,35 \mathrm{Bb}$ & $24,46 \mathrm{Bab}$ & $30,39 \mathrm{Aa}$ \\
\hline Lignina & & & & & & & \\
Testemunha & $4.71 \mathrm{Aa}$ & $4.35 \mathrm{Aa}$ & $3.82 \mathrm{Aa}$ & $5.02 \mathrm{Aa}$ & $4.94 \mathrm{Aa}$ & $4.93 \mathrm{Aa}$ & $5.07 \mathrm{Aa}$ \\
Uréia & $4.90 \mathrm{Aa}$ & $4.64 \mathrm{Aa}$ & $3.26 \mathrm{Aa}$ & $3.24 \mathrm{Aa}$ & $4.13 \mathrm{Aa}$ & $4.71 \mathrm{Aa}$ & $5.17 \mathrm{Aa}$ \\
Zeólita & $4.15 \mathrm{Aa}$ & $4.42 \mathrm{Aa}$ & $4.21 \mathrm{Aa}$ & $4.19 \mathrm{Aa}$ & $4.79 \mathrm{Aa}$ & $5.53 \mathrm{Aa}$ & $5.23 \mathrm{Aa}$ \\
Uréia/zeólita & $4.77 \mathrm{Aa}$ & $4.89 \mathrm{Aa}$ & $3.96 \mathrm{Aa}$ & $3.32 \mathrm{Aa}$ & $4.65 \mathrm{Aa}$ & $4.78 \mathrm{Aa}$ & $4.55 \mathrm{Aa}$ \\
IB & $4.19 \mathrm{Aa}$ & $3.43 \mathrm{Aa}$ & $4.17 \mathrm{Aa}$ & $4.92 \mathrm{Aa}$ & $4.12 \mathrm{Aa}$ & $5.38 \mathrm{Aa}$ & $5.15 \mathrm{Aa}$ \\
IBE & $4.74 \mathrm{Aa}$ & $4.03 \mathrm{Aa}$ & $3.79 \mathrm{Aa}$ & $4.97 \mathrm{Aa}$ & $4.25 \mathrm{Aa}$ & $4.31 \mathrm{Aa}$ & $5.01 \mathrm{Aa}$ \\
\hline IB
\end{tabular}

$\mathrm{IB}=$ inoculante bacteriano $(\operatorname{Silobac} \mathbb{R}) ; \mathrm{IBE}=$ inoculante bacteriano/enzimático (BioMax ${ }^{\circledR}$ cana).

Valores seguidos por letras distintas, maiúsculas na linha e minúsculas na coluna, diferem entre si pelo teste $\mathrm{SNK}(\mathrm{P}<0,05)$. $\mathrm{CV}($ celulose $)=4,9 \% ; \mathrm{CV}($ Hemicelulose $)=4,4 \% ; \mathrm{CV}($ lignina $)=17,3 \%$.

Diferenças significativas nas concentrações de hemicelulose entre as silagens foram somente observadas a partir do $14^{\circ}$ dia de abertura dos silos, no qual a silagem testemunha apresentou o maior valor médio $(27,61 \%)$, porém não diferiu $(\mathrm{P}>0,05)$ dos valores apresentados pelas silagens tratadas com uréia, uréia+zeólita e inoculante bacteriano. No $56^{\circ}$ dia, as silagens testemunha e tratadas com zeólita, inoculante bacteriano e inoculante bacteriano/enzimático apresentaram maiores concentrações de hemicelulose. Em relação ao avanço do processo fermentativo, a concentração de hemicelulose aumentou em todas as silagens. Entretanto, um aumento significativo foi observado no $7^{\circ}$ dia de fermentação nas silagens tratadas com zeólita, inoculante bacteriano e inoculante bacteriano/enzimático; no $14^{\circ}$ dia, na silagem testemunha e, no $56^{\circ}$ dia, na silagem tratada com uréia e uréia + zeólita. Kung Jr. e Stanley (1982) e Alcântara et al. (1989), ao trabalharem com a cana-de-açúcar ensilada, também observaram aumento na concentração de hemicelulose.

Não houve diferença significativa nas concentrações de lignina entre as silagens submetidas aos diferentes tratamentos. Os teores de lignina permaneceram estáveis durante a fermentação em todos os tratamentos avaliados. Segundo Morrison (1979), os microrganismos presentes na silagem são incapazes de degradar a lignina. Pedroso (2003) observou menor concentração de lignina na silagem de cana-deaçúcar (RB785841) tratada com $0,5 \%$ de uréia 
em relação à silagem controle $(7,03 \%$ x 7,86\%). Entretanto, o uso de cepas de L. plantarum aumentou a concentração de lignina $(9,19 \%)$.

$\mathrm{Na}$ Tab. 8 encontra-se o coeficiente da digestibilidade in vitro da matéria seca (DIVMS) das silagens de cana-de-açúcar. Não foram verificadas diferenças significativas nos coeficientes de DIVMS entre as silagens submetidas aos diferentes tratamentos nos dias um, três, cinco e 56. Nos dias sete, 14 e 28 da fermentação, a silagem tratada com uréia apresentou maior valor de DIVMS, porém diferindo $(\mathrm{P}<0,05)$ apenas dos tratamentos zeólita, testemunha e testemunha, respectivamente. Observou-se redução dos coeficientes de DIVMS ao longo do processo fermentativo, sendo essa redução significativa a partir do $7^{\circ}$ dia para a silagem tratada com zeólita e inoculante bacteriano, do $14^{\circ}$ dia para a silagem testemunha e tratada com inoculante bacteriano/enzimático e, somente no $28^{\circ}$ dia para as silagens tratadas com uréia e uréia+zeólita. Pode-se observar que a uréia retardou a redução da DIVMS durante a ensilagem, entretanto não foi capaz de sustentá-la até o último dia de fermentação. Pedroso (2003) observou redução significativa da DIVMS da cana-de-açúcar ensilada em relação à forragem fresca $(47,1 \% \mathrm{x}$ $62,9 \%)$.

Tabela 8. Coeficientes de digestibilidade in vitro da matéria seca das silagens de cana-de-açúcar (RB72454, submetidas a diferentes tratamentos e avaliadas em diferentes dias após a ensilagem, expressas em porcentagem da matéria seca

\begin{tabular}{lccccccc}
\hline \multirow{2}{*}{ Tratamento } & \multicolumn{7}{c}{ Dias de ensilagem } \\
\cline { 2 - 7 } & 1 & 3 & 5 & 7 & 14 & 28 & 56 \\
\hline Testemunha & $58,38 \mathrm{Aa}$ & $58,85 \mathrm{Aa}$ & $57,45 \mathrm{Aa}$ & $54,48 \mathrm{Aab}$ & $48,63 \mathrm{Bb}$ & $45,90 \mathrm{Bb}$ & $46,48 \mathrm{Ba}$ \\
Uréia & $59,65 \mathrm{Aa}$ & $59,83 \mathrm{Aa}$ & $57,83 \mathrm{ABa}$ & $59,40 \mathrm{Aa}$ & $56,28 \mathrm{ABa}$ & $52,55 \mathrm{BCa}$ & $48,40 \mathrm{Ca}$ \\
Zeólita & $58,48 \mathrm{Aa}$ & $58,43 \mathrm{Aa}$ & $56,95 \mathrm{Aa}$ & $51,70 \mathrm{Bb}$ & $51,85 \mathrm{Bab}$ & $49,35 \mathrm{Bab}$ & $46,88 \mathrm{Ba}$ \\
Uréia/zeólita & $58,43 \mathrm{Aa}$ & $58,33 \mathrm{Aa}$ & $58,10 \mathrm{Aa}$ & $57,68 \mathrm{Aab}$ & $53,20 \mathrm{ABab}$ & $50,33 \mathrm{Bab}$ & $51,15 \mathrm{Ba}$ \\
IB & $59,78 \mathrm{Aa}$ & $58,33 \mathrm{ABa}$ & $55,55 \mathrm{ABCa}$ & $53,23 \mathrm{BCab}$ & $52,48 \mathrm{BCab}$ & $49,93 \mathrm{CDab}$ & $45,88 \mathrm{Da}$ \\
IBE & $61,03 \mathrm{Aa}$ & $59,43 \mathrm{ABa}$ & $59,98 \mathrm{ABa}$ & $55,25 \mathrm{ABab}$ & $53,70 \mathrm{Bab}$ & $54,10 \mathrm{Ba}$ & $46,98 \mathrm{Ca}$ \\
\hline
\end{tabular}

$\mathrm{IB}=$ inoculante bacteriano $(\operatorname{Silobac} \AA) ; \mathrm{IBE}=$ inoculante bacteriano/enzimático (BioMax $®$ cana).

Valores seguidos por letras distintas, maiúsculas na linha e minúsculas na coluna, diferem entre si pelo teste $\mathrm{SNK}(\mathrm{P}<0,05)$. $\mathrm{CV}=4,1 \%$.

\section{CONCLUSÕES}

A ensilagem de cana-de-açúcar foi caracterizada por perdas de matéria seca e carboidratos solúveis, resultando em acúmulo dos componentes da parede celular (FDN, FDA, celulose e hemicelulose) e redução da digestibilidade in vitro da matéria seca. Os aditivos avaliados não foram eficientes em evitar as perdas durante a fermentação. Dessa forma, o valor nutricional da cana-de-açúcar não foi preservado. Nota-se a necessidade de mais estudos, com aprofundamento nos ensaios de produção animal, a fim de se verificar a viabilidade da utilização da silagem de cana-deaçúcar, na alimentação de ruminantes.

\section{REFERÊNCIAS BIBLIOGRÁFICAS}

ALCANTARA, E.; AGUILERA, A.; ELLIOT, R. et al. Fermentation and utilization by lambs of sugarcane harvested fresh and ensiled with and without NaOH. IV. Ruminal kinetcs. Anim. Feed Sci. Technol., v.23, p.323-331, 1989.
ALLI, I.; BAKER, B.E. Studies on the fermentation of chopped sugarcane. Anim. Feed Sci. Technol., v.7, p.411-417, 1982.

ALLI, I.; FAIRBAIN, R.; BAKER, B.E. The effect of ammonia on the fermentation of chopped sugar cane. Anim. Feed Sci. Technol., v.9, p.291-299, 1983.

ANTUNES, R.C. Padrão de fermentação das silagens de seis genótipos de milho (Zea_mays L.). 2001. 50f. Dissertação (Mestrado) - Escola de Veterinária, Universidade Federal Minas Gerais, Belo Horizonte.

BAILEY, R.W. Quantitative studies of ruminant digestion of ingested plant carbohydrates from the reticulo-rumen. N. Zeal. J. Agric. Res., v.10, p.15-32, 1967.

BANDA, M.; VALDEZ, R.E. Effect of stage of maturity on nutritive value of sugar cane. Trop. Anim. Prod., v.1, p.94-97, 1976.

BULLETIN of statistics. v.3. Roma: FAO, 2002. $144 \mathrm{p}$. 
BURGI, R. Cana-de-açúcar. In: SIMPÓSIO SOBRE NUTRIÇÃO DE BOVINOS. 6., 1995, Piracicaba. Anais... Piracicaba: FEALQ, 1995. p.153-169.

CASTRO NETO, A.G. Avaliação de silagens de cana-de-açúcar submetidas a diferentes tratamentos. 2003. 53f. Dissertação (Mestrado) Escola de Veterinária, Universidade Federal de Minas Gerais, Belo Horizonte.

KUNG Jr., L.; STANLEY, R.W. Effect of stage of maturity on the nutritive value of whole-plant sugarcane preserved as silage. J.Anim.Sci., v.54, p.689-696, 1982.

LANDELL, M.G.A.; CAMPANA, M.P.; RODRIGUES, A.A. et al. A variedade IAC862480 como nova opção de cana-de-açúcar para fins forrageiros: manejo de produção e uso na alimentação animal. Campinas: Instituto Agronômico de Campinas, 2002. 36p. (Boletim técnico IAC 193).

McDONALD, P.; HENDERSON, A.R.; HERON, S.J.E. The biochemistry of silage. 2.ed. Marlow: Chalcombe Publications, 1991. 340p.

MOLINA, A.S.; SIERRA, J.F; FEBLES, I. Sugar cane silage with protein synthesis: combined effect of additives and density. Cuban J. Agric. Sci., v.33, p.205-208, 1999.

MORRISON, I.M. Changes in the cell wall components of laboratory silages and the effect of various additives on these changes. J. Agric. Sci., v.93, p.581-586, 1979.

OFFICIAL methods of analysis. 16.ed. Washington: AOAC, 1995. 2000p.

OLIVEIRA, M.D.S.; SAMPAIO, A.A.M.; CASAGRANDE, A.A. et al. Efeito de variedades de cana-de-açúcar sobre a composição químico-bromatológica. In: REUNIÃO ANUAL DA SOCIEDADE BRASILEIRA DE ZOOTECNIA, 35., 1998, Botucatu. Anais... Botucatu: SBZ 1998. p. 275277.

PEDROSO, A.F. Aditivos químicos $e$ microbianos no controle de perdas e na qualidade de silagem de cana-de-açúcar (Saccharum officinarum L.). 2003. 120f. Tese (Doutorado) - Escola Superior de Agricultura Luiz de Queiróz, Universidade de São Paulo, Piracicaba.

PEIXOTO, A.M. A cana-de-açúcar como recurso forrageiro. In: CONGRESSO BRASILEIRO DE PASTAGEM E SIMPÓSIO SOBRE MANEJO DE PASTAGENS, 8., 1986, Piracicaba: FEALQ, 1986. p.17-47.

PRESTON, T.R.; HINOJOSA, C.; MARTINEZ, L. Ensiling os sugar cane with ammonia, molasses and mineral acids. Trop. Anim. Prod., v.1, p.120-126, 1976.

RODRIGUES, A.A.; CRUZ, G.M.; BATISTA, L.A.R. et al. Qualidade de dezoito variedades de cana-de-açúcar como alimento para bovinos. In: REUNIÃO DA SOCIEDADE BRASILEIRA DE ZOOTECNIA, 38., 2001, Piracicaba. Anais...Piracicaba: SBZ, 2001. p.1111-1113.

SILVA, S.C. A cana-de-açúcar como alimento volumoso suplementar. In: PEIXOTO, A.M.; MOURA, J.C.; FARIA, V.P. (Eds). Volumosos para bovinos. Piracicaba: FEALQ, 1993. p.5974.

SISTEMA de análise estatísticas e genéticas SAEG. Versão 7.1. Viçosa, MG: UFV, 1997. p. 150 .

TILLEY, J.M.A.; TERRY, R.A. A two-stage technique for the in vitro digestion of forage crops. J. Br. Grassl. Soc., v.18, p.104-111, 1963.

VALADARES FILHO, S. C. Digestibilidades aparentes e locais de digestão da matéria seca, energia e carboidratos de fenos de soja perene. 1981. 88f. Dissertação (Mestrado) - Escola de Veterinária, Universidade Federal de Minas Gerais, Belo Horizonte.

VAN SOEST, P.J.; ROBERTSON, J.B.; LEWIS, B.A. Methods for dietary fiber, neutral detergent and nonstarch polysaccharides in relation to animal nutrition. .J. Dairy Sci., v.74, p.35833597, 1991. 